\title{
Gruber, Gradenigo, Dorello, and Vail: key personalities in the historical evolution and modern-day understanding of Dorello's canal
}

\author{
Renuka K. Reddy, BS, ${ }^{1}$ Rohit K. Reddy, BS, ${ }^{1}$ Robert W. Jyung, MD, ${ }^{2}$ Jean Anderson Eloy, MD, ${ }^{1-3}$ \\ and James K. Liu, MD ${ }^{1-3}$
}

Departments of ${ }^{1}$ Neurological Surgery and ${ }^{2}$ Otolaryngology_-Head \& Neck Surgery, Rutgers University, New Jersey Medical School; and ${ }^{3}$ Center for Skull Base and Pituitary Surgery, Neurological Institute of New Jersey, Rutgers University, New Jersey Medical School, Newark, New Jersey

\begin{abstract}
A century ago an ambitious young anatomist in Rome, Primo Dorello, who sought to understand the cause of abducent nerve palsy that often occurred in patients with severe middle ear infections, conducted intricate studies on the intracranial course of the nerve. In his findings, he identified that the abducent nerve passes through a narrow sinus near the apex of the petrous bone, which formed an osteofibrous canal. Dorello suggested that in this enclosed region the abducent nerve may be particularly vulnerable to compression due to the vascular edema accompanying the infection. Although his work was widely appreciated, it was not well received by all. Interestingly, Giuseppe Gradenigo, one of the most prominent Italian otologists of the early 20th century, who was known for his work on a triad of symptoms (Gradenigo's syndrome) that accompanies petrous apicitis, a result of severe middle ear infections, was obstinate in his criticism of Dorello's findings. Thus a scientific duel began, with a series of correspondence between these two academics-one who was relatively new to the otological community (Dorello) and one who was well reputed in that community (Gradenigo). The disagreement ultimately ebbed in 1909, when Dorello published a report in response to Gradenigo's criticisms and convinced Gradenigo to change his views.

Today Dorello's canal is widely recognized as a key landmark in skull base surgery of the petroclival region and holds clinical significance due to its relation to the abducent nerve and surrounding vascular structures. Yet, although academics such as Dorello and Gradenigo are recognized for their work on the canal, it is important not to forget the others throughout history who have contributed to the modern-day understanding of this anatomical structure. In fact, although the level of anatomical detail found in Dorello's work was previously unmatched, the first description of the canal was made by the experienced Austrian anatomist Wenzel Leopold Gruber in 1859, almost 50 years prior to Dorello's landmark publication. Another critical figure in building the understanding of Dorello's canal was Harris Holmes Vail, a young otolaryngologist from Harvard Medical School, who in 1922 became the first person to describe Dorello's canal in the English language. Vail conducted his own detailed anatomical studies on cadavers, and his publication not only reaffirmed Dorello's findings but also immortalized the eponym used today_"Dorello's canal."
\end{abstract}

In this article the authors review the life and contributions of Gruber, Dorello, Gradenigo, and Vail, four men who played a critical role in the discovery of Dorello's canal and paved the way toward the current understanding of the canal as a key clinical and surgical entity.

http://thejns.org/doi/abs/10.3171/2014.12.JNS14835

KEY WORDS Dorello's canal; Wenzel Gruber; Giuseppe Gradenigo; Primo Dorello; Harris Vail; abducent palsy; history

$\mathrm{D}$ ORELLO's canal is an osteofibrous passage formed by a narrow depression near the tip of the petrous bone. It is located behind Gruber's petrosphenoidal ligament, between the petrous apex and the clivus. Typically, the abducent nerve passes through this canal as it traverses the petroclival region. Although the structure was originally described by Gruber in $1859,{ }^{31}$ widespread clinical interest in the canal only grew during the early 1900s after Dorello ${ }^{19}$ identified the enclosed region as a potential site of abducent nerve constriction, leading to abducent palsies - a characteristic of Gradenigo's syndrome. ${ }^{22,25,26}$ In the years surrounding Dorello's detailed anatomical studies, interest in the canal surged.$^{20}$ In 1922 , after reading the works of Dorello and Gradenigo, Har- 
ris $\mathrm{H}$. Vail ${ }^{56}$ a young otolaryngologist at Harvard Medical School, became the first to describe the anatomy of the canal in the English literature. After Vail, however, interest in Dorello's canal dwindled as questions surrounding Gradenigo's syndrome were resolved and the use of antibiotics increased-decreasing the incidence of severe otitis media and the need for surgery. . $^{13,16,20,40}$

Clinical interest in the canal was not reestablished until the 1970s, when novel microscopic techniques and improved surgical equipment made accessing and studying the petroclival region less difficult. 17,18,36,37,45,53,55 The modern clinical interest was focused on Dorello's canal as a potential site for abducent nerve damage following traumatic brain injury, hydrocephalus, intracranial aneurysms, ${ }^{4}$ or intrusion by petroclival tumors, ${ }^{1,44}$ due to the nerve's vulnerable passage through the narrow canal. ${ }^{38,41,47}$ While there has been a resurgence of interest in the anatomy of the petroclival region and Dorello's canal in recent years due to rapid advances in skull base surgery, it is essential to look at the seminal works that built the understanding of this anatomical structure and appreciate the transitions and growth of clinical knowledge over time. It is inspiring to note the attention to detail and the level of dedication exemplified by these historical figures in their studies of one of the most complex regions of the skull base during an era when such anatomical studies and clinical investigations were conducted without the conveniences of modern microanatomical technology. In this paper, we present a historical review of the personal lives and contributions of key figures involved in the discovery and understanding of Dorello's canal. We begin with Gruber and his initial descriptions of the anatomy of the petroclival region, followed by Gradenigo and Dorello, and their pivotal works on the canal with respect to abducent palsy in ear infections, and conclude with Vail and his role in reinforcing Dorello's description of the canal.

\section{Wenzel Leopold Gruber (1814-1889)}

Born on December 24, 1814, in the village of Krukanitz in Bohemia, Czech Republic, Wenzel Leopold Gruber (Fig. 1) was the first to describe Dorello's canal while investigating the structures of the sphenoid bone. As a child, Gruber completed his early education at a parochial school in Marienbad and at Gymnasium (German secondary school). He later attended Charles University in Prague to study medicine, and obtained his degree in $18444^{2,15}$ From 1842 to 1847 , Gruber worked at Charles University as the prosector of normal anatomy. ${ }^{2,15}$ During this time, Gruber grew into a skilled anatomist through the guidance of Joseph Hyrtl and Vincenz Alexander Bochdalek, professors of anatomy at the university. For his scientific accomplishments, Gruber was elected as a member of the anatomy section of the German Academy of Sciences Leopoldina (http://www.leopoldina.org/en/members/list-of-members/ member/3047/). In 1847, Gruber received an offer from a prominent Russian physician, Nicolai Ivanovich Pirogov, to join him at the Medical Academy of St. Petersburg in Russia as the first prosector of normal human anatomy at the institution..$^{2,15}$ In 1855, Gruber succeeded Pirogov as the director of the department of anatomy at the acad- emy, ${ }^{15,39,50}$ and eventually obtained full professorship in $1858.2,15$

During his early years as a professor, Gruber studied cranial anatomy. One of the first regions he focused on was the sphenoid and temporal bone. In 1859, Gruber published his findings in an article titled "[Contributions to the anatomy of the sphenoid and the temporal bone]," ${ }^{31}$ which outlined his observations of the anatomy of the skulls of various primate species. It was in this paper that he described the petrosphenoidal ligament, now recognized as "Gruber's ligament," and the canal behind the ligament, which he named foramen petrosphenoideum, but which is known today as "Dorello's canal" (Fig. 2). The osteofibrous canal, according to Gruber's observations, was found at the tip of the petrous bone and was $6-12 \mathrm{~mm}$ long and 1-3 mm wide. Gruber noticed that both the abducent nerve and the inferior petrosal sinus passed through the canal. He also noted that the petrosphenoidal ligament, which stretches from the petrous apex to the posterior clinoid process of the sphenoid, leads to the entrance of the canal. Interestingly, during his studies of 13 skulls of Simia satyrus (orangutan), Gruber initially missed identifying the bony canal. However, on further inspection he noted the occurrence of the ossified petrosphenoidal ligament and the foramen petrosphenoideum, and made sure to report that this occurrence appeared to be a rule rather than an exception in this primate species. In his article he also described similar findings about the osteofibrous canal in humans. ${ }^{31}$ Although he did not pursue many more detailed studies of the canal, he wrote, in an almost clairvoyant manner: "[This hole, which to my knowledge has not yet [been] described by any anatomist, is not a meaningless curiosity, but, in so far as it is a formation that is sometimes present in the human skull and is present consistently in certain animals, it is an interesting occurrence.]"31

Thus, through his keen perception, Gruber noticed the importance of the canal and set the stage for future investigations of this structure-the most critical of which would arise nearly 50 years later in Italy in the form of a debate between an experienced otologist, Giuseppe Gradenigo, and a budding anatomist, Primo Dorello. ${ }^{19,23}$

Following up on his studies of cranial anatomy, in 1869 Gruber published other works on the study of the skull base. ${ }^{28,30}$ However, Gruber's anatomical interests extended well beyond the skull. Among his more than 500 comprehensive publications $^{2}$ were studies of vascular abnormalities, ${ }^{32}$ polydactyly, ${ }^{54}$ internal mesogastric hernias (known as "Gruber's hernia"), musculature, ${ }^{33}$ skeletal structures, ${ }^{27,29}$ and hermaphroditism-making him a true connoisseur of anatomy and pathology. He left an everlasting impression in Russia, not only through his numerous publications but also through his efforts to promote expanded anatomy education through Russian institutes and to build an institute of anatomy and physiology associated with the University of St. Petersburg. ${ }^{2}, 15$ After nearly 40 years as Professor of Anatomy in Russia, Gruber moved to Vienna, Austria in $1888 .{ }^{15}$ His contributions were also recognized worldwide, and in 1888 he received an honorary degree in Medicine and Surgery from the University of Bologna (http://www.archiviostorico.unibo.it/it/strutturaorganizzativa/sezione-archivio-storico/lauree-honoris- 


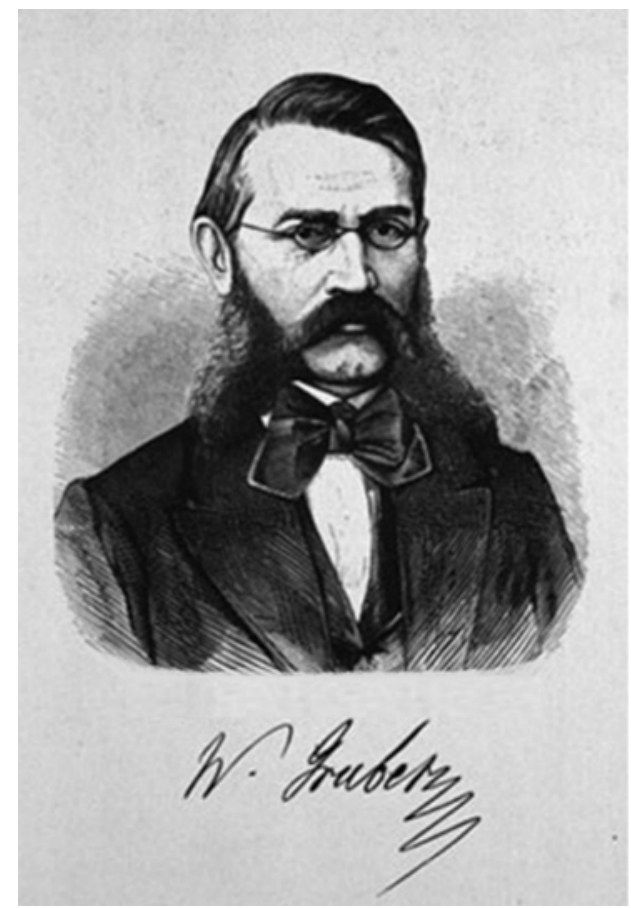

\author{
MÉMOIRES \\ $\mathrm{DE}$ \\ L'ACADÉMIE IMPÉRIALE DES SCIENCES DE ST.-PÉTERSBOLRG, VII SÉRIE. \\ TOME I, N’ 3.
}

BeITRIGE ZUR aNaTOMIR
KEILBEINES UND SCHLÄFENBEINES.

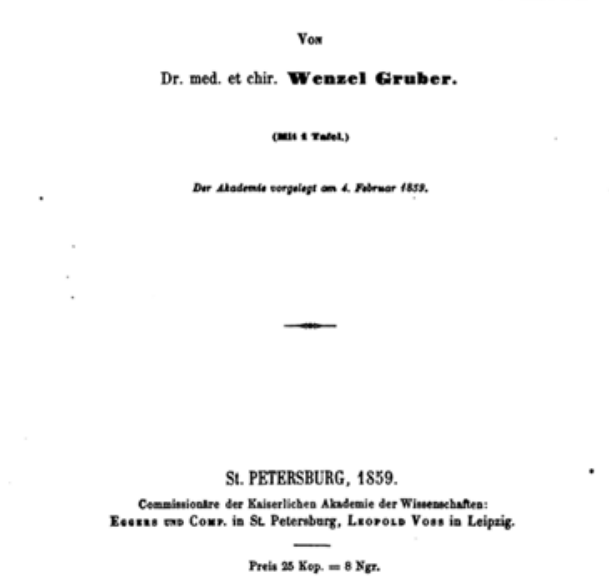

FIG. 1. Left: Portrait of Wenzel Leopold Gruber. Right: Cover page of Gruber's 1859 landmark publication describing the petrosphenoidal ligament and foramen. From Gruber W: Mémoires de l'Académie Impériale des Sciences de St. Pétersbourg, VIle série 1(3):3-13, 1859.

causa/wenzel-weneslaus-leopold-gruber.asp?IDFolder=3 $33 \&$ IDOggetto $=112357 \& \mathrm{LN}=\mathrm{IT}$ ), the oldest university in Italy.

On September 30, 1889, at the age of 76, Gruber died..$^{2,15}$ His life and work was celebrated in several medical jour- nals, including the Boston Medical and Surgical Journal, ${ }^{10}$ Nature ${ }^{46}$ and the British Medical Journal ${ }^{11}$ - which noted his tremendous dedication to anatomy, stating that it is often remarked that he must have dissected no fewer than 20,000 bodies during his prolific career.
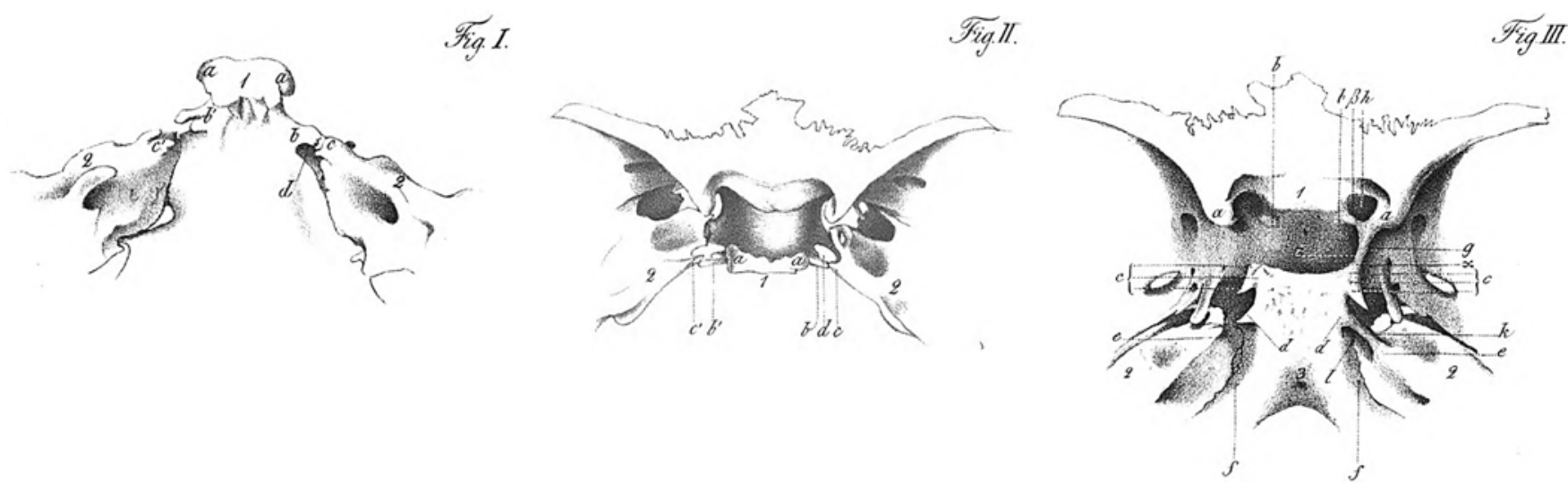

FIG. 2. Original illustrations from Gruber's 1859 publication describing the structures of the sphenoid and temporal bones. Fig I: Front wall of the posterior fossa. Fig II: Middle cranial fossa. Labels in Figs. I and II: 1, dorsum sellae; 2, pyramidal or petrous part of temporal bone; $a$, processus clinoideus posterior superior (superior posterior clinoid process); $b$ and b', processus clinoideus posterior inferior (inferior posterior clinoid process); $c$ and c', processus sphenoidales posterior (posterior sphenoid process); $d$, foramen petrosphenoideum osseum (bony petrosphenoidal foramen) or Dorello's canal. Fig. III: Middle cranial fossa. Labels in Fig. III: 1, sphenoid bone; 2, pyramidal or petrous part of temporal bone; 3 , basilar part of the occipital bone; a, processus clinoid ant. (anterior clinoid process); b, processus clinoid med. (medial clinoid process); c, processus clinoid post. sup. (superior posterior clinoid process); d, processus clinoid post. inf. (inferior posterior clinoid process); e, processus sphenoid post. (posterior sphenoid process); f, sulci petrosi inf. (inferior petrosal sulcus); $g$, ligamentum interclinoideum (interclinoid ligament); $\alpha$, horizontal limb of the interclinoid ligament; $\beta$, ascending limb of the interclinoid ligament; $h$, ligamentum petrosphenoideum post. (posterior petrosphenoidal ligament); i, foramen petrosphenoideum osteofibrosum (osteofibrous petrosphenoidal foramen); k, petrosphenoidal ligament; I, foramen petrosphenoidem (Dorello's canal). From Gruber W: Mémoires de l'Académie Impériale des Sciences de St. Pétersbourg, VIle série 1(3):3-13, 1859. 


\section{Giuseppe Gradenigo (1859-1926)}

Giuseppe Gradenigo (Fig. 3) was a renowned figure in the Italian otological community of the late 19th and early 20th centuries; he was known throughout the world for his work on "Gradenigo's syndrome," a triad of symptoms that accompanies petrous apicitis, and his extensive leadership and authority in the developing field of otolaryngology. ${ }^{12,20,42,51,52}$ Gradenigo was born on September 29, 1859 , in Venice, Italy, to a family of respected and influential Venetians. After completing his medical training at the University of Padua in 1877, Gradenigo moved to Vienna to work with his mentor, Adam Politzer, the legendary father of European otology. He also attended the Institute of Embryology, led by Samuel Leopold Schenk, to study the embryonic development of the ear. ${ }^{24}$ In 1888, Gradenigo accepted a private lecturer position at the University of Padua. Within a year, he earned a position in Turin's Polyclinic as the head of the Department of Otolaryngology, where he created additional clinics for the poor and developed an otolaryngology training program.12,42,52

In 1891, along with several of his peers, Gradenigo initiated the Italian Society of Laryngology, Otology, and Rhinology. ${ }^{12,42,51,52}$ In 1896 he was promoted to the position of Professor of Otology in Turin. It was in the following years that Gradenigo studied a range of subjects, including audiology, but the topic he paid special attention to was otitis media. In 1904, Gradenigo published reports describing the triad of symptoms that results from severe otitis media and infection of the petrous apex of the temporal bone, which came to be known as "Gradenigo's syndrome." $22,25,26$ The syndrome consists of 1) purulent and suppurative ear infection, along with 2) trigeminal neuralgia (severe facial pain), and 3) ipsilateral abducent nerve palsy, which causes paralysis of the lateral rectus muscle. ${ }^{16,20,22,25,26,38,40}$ Through his extensive work on the subject, Gradenigo was widely regarded as an expert on the symptomatology of severe otitis media, and his description was undisputed. ${ }^{20}$ However, questions remained regarding the pathogenesis of the disease, particularly the cause of the abducent palsy. Several mechanisms of sixth cranial nerve involvement were put forward by members of the otological community. Gradenigo proposed that whereas the infection originated in the tympanic cavity, it spread inward, eventually affecting the leptomeninges and causing suppurative and purulent leptomeningitis with inflammation that damaged the sixth cranial nerve, resulting in abducent palsy. ${ }^{22,25,26}$ Some, like Mongardi ${ }^{43}$ suggested that the infection had spread deeply from the tympanic cavity to the cavernous sinus via passage through the carotid canal, resulting in extensive inflammation within the cavernous sinus and tissues surrounding the abducent nerve. Following up on Gradenigo's case reports and hypothesis, Citelli ${ }^{14}$ proposed that the infection was relatively localized to the ear and might spread within a narrow region, resulting in proximal pachymeningitis of the petrous apex. Others believed that the infection had more long-term consequences and greatly affected central nuclei cells. ${ }^{18}$

The debate continued until Primo Dorello (Fig. 4) entered the scene at the age of 33. In 1905, he published his observations from dissections of the intracranial path of the abducent nerve, in an article titled "[Considerations concerning the cause of temporary paralysis of the abducent in middle ear inflammation]." 19 In his landmark report, Dorello suggested that paralysis of the abducent

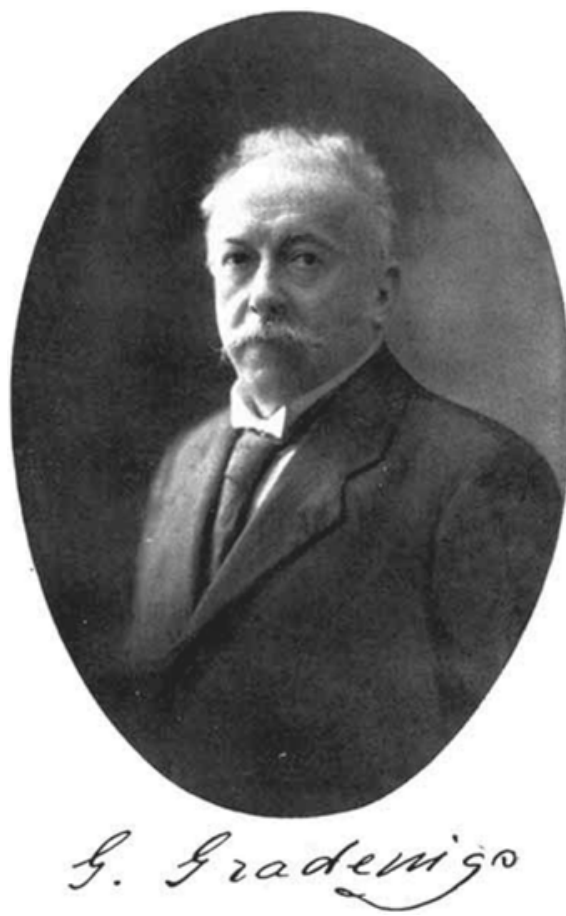

xxxiv.

Sulla paralisi dell'abducente di origine otitica

(617.89)

Prof. G. GRadenigo

Nelle sedute del 29 gennaio, del 22 aprile e del 17 giugno u.s. della R. Accademia di Medicina di Torino io stabilivo la esistenza di una particolare sindrome morbosa caratterizzata da otite media acuta, da dolori assai intensi e tenaci all'orecchio malato e alla metá corrispondente della testa e dalla comparsa, dopo un periodo di tempo di solito variabile da 3 settimane ad $1 \frac{1 / 2}{2}$ mese dall'inizio della otite, di una paresi o paralisi isolata del retto esterno oculare dal lato dell'orecchio malato. Ho avuo occasione di osservare e di pubblicare 6 casi di tale affezione, dei quali 5 passarono a guarigione completa e 1 terminó colla morte per insorgenza di leptomeningite purulenta diffusa. Con ogni probabilitả si tratta in tale malattia di un focolaio circoscritto di leptomeningite, sia purulenta, sia semplicemente sierosa, dovuto ad infezione propagatasi alle pie meningi dalla cassa timpanica; questo focolaio meningitico passa per lo più a guarigione col guarire della malattia dell'osso temporale, ma in taluni casi dà luogo a meningite generalizzata.

Dispersi nella letteratura otologica ho trovato soltanto 4 casi che corrispondono perfettamente alla sindrome da me descritta, dovuti cioè a Spira ${ }^{1}, \mathrm{Pischel}^{2}, \mathrm{D}^{\prime} \mathrm{Ajutol} 0^{3}$ e Tōrōk 4 ; tale rarità è probabilmente solo apparente e dovuta al fatto che per la loro ordinaria benignità tali casi non sono stati ritenuti degni di pubblicazione ${ }^{5}$. In questa opinione io sono confermato da ció,

FIG. 3. Left: Portrait of Giuseppe Gradenigo. Right: One of Gradenigo's 1904 landmark papers describing the paralysis of the abducent nerve due to otitis media. His extensive work on the symptomatology of these cases of otological infections led to his thorough description of Gradenigo's syndrome. From Gradenigo G: Arch Ital Otol Rinol Laringol 15:402-403, 1904 (Italian). 


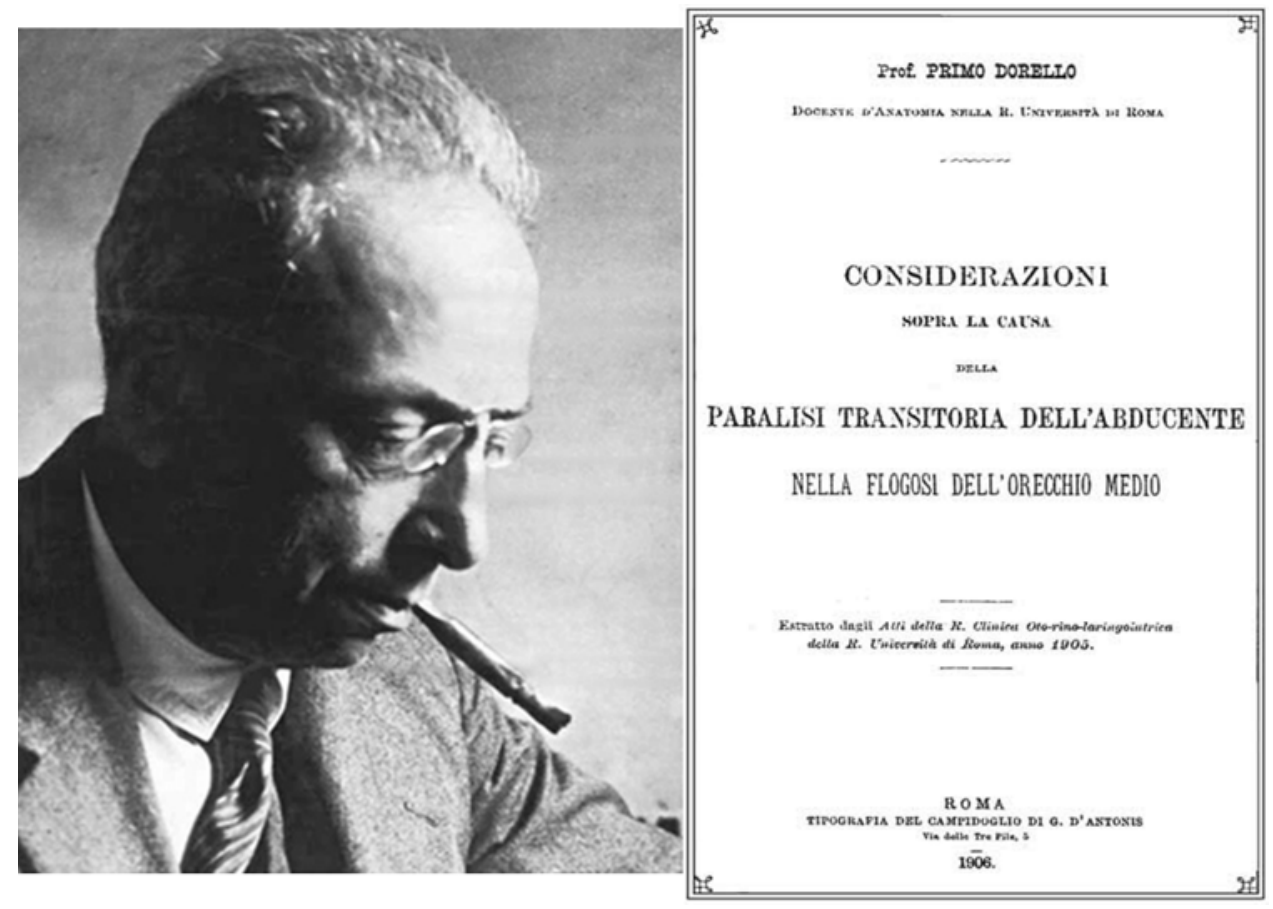

FIG. 4. Left: Portrait of Primo Dorello. Right: Cover page of Dorello's landmark 1905 publication describing the osteofibrous canal and the potential cause of abducent nerve palsy in severe otitis media. From Dorello P: Atti della Clinica Oto-Rino-Laringoiatrica della R. Universitá di Roma 3:209-217, 1905.

was due to the particularly vulnerable intracranial position of the nerve. He proposed that the infection passed through the tympanic veins to the petrosal sinus, causing inflammatory edema and compression of the nerve at a narrowing near the apex of the petrous bone. This narrowing, when bounded from above by the petrosphenoidal ligament of Gruber, forms an enclosed, rigid, osteofibrous canal-a tight and vulnerable region through which the nerve traverses en route to the lateral rectus muscle of the eye. Dorello explained that the paralysis of the nerve is only temporary and disappears soon after the localized compression is relieved, leaving behind little to no permanent damage. 19,20,23,56

In the following years several others, such as Baldenweck ${ }^{7}$ and Baratoux, ${ }^{8}$ published anatomical reports and reviews of the literature that supported Dorello's ideas regarding the temporary paralysis of the abducent. ${ }^{7,8,20}$ Nevertheless, Gradenigo, who responded to these new advancements in his 1907 review of various case reports on acute abducent paralysis in otitis media, was staunch in insisting that Dorello's findings were flawed:

[This hypothesis is certainly very seductive; only, it is contrary to anatomical and clinical facts, so that is untenable in the great majority of cases... The veins of the tympanic cavity belong to the district of the pharyngeal plexus, of the meningea media vein, of the internal and external jugular vein and, consequently, have no direct relationship with the inferior petrosal sinus ... Dorello's hypothesis is eventually unable to explain the observed deaths with symptoms of leptomeningitis. $]^{23}$

Gradenigo doubted the accuracy of Dorello's descriptions and denied that the tympanic veins had any direct relationship with the inferior petrosal sinus, among other criticisms. ${ }^{23}$ In a recent paper, Felisati and Sperati relate that, in an astute response, Dorello referred Gradenigo to the anatomical findings of Politzer, Gradenigo's own mentor. ${ }^{20}$ In his studies of the human ear, Politzer found that the vasculature of the middle ear and tympanic cavity was indeed related to the petrosal sinus, a finding that had since been confirmed by other published anatomical texts. ${ }^{48}$

In a surprising turn of events, the experienced otological master, Gradenigo, reluctantly withdrew his firm disagreement concerning the site of abducent paralysis in favor of the hypothesis of Dorello, an emerging anatomist. ${ }^{20}$ It became clear that Gradenigo's original hypothesis on leptomeningitis was not plausible. At the site of infection proposed by Gradenigo, the abducent would not be affected by meningitic processes because it had already entered the dura mater. His hypothesis also could not explain why the third and fourth cranial nerves were not affected by the inflammation, which Dorello's explanation of infection within the isolated osteofibrous canal accounted for very well. Ultimately the debate ebbed, as members of the otological community consolidated their ideas around those of Dorello, and thus resolved one of the most tenacious debates of their time..$^{19,20}$

A few years after the controversy, on March 15, 1926, Italy lost an important member of the otological community. ${ }^{3,12,52}$ After a highly prolific career with more than 400 publications, Gradenigo, who at the time was the director of the Otorhinolaryngology Clinic at the University of Naples, ${ }^{3}$ died at the age of 66 . His life was honored not only for his contributions to otorhinolaryngology, but also for his valuable medical services as a lieutenant colonel in the Allied forces during World War I..$^{12,42,52}$ 
Looking back, while there were disagreements and debates between Gradenigo and Dorello, it is now clear that these spirited communications served to challenge conventional thinking and strengthen the understanding of the canal. Through his skeptical discussion of Dorello's work, Gradenigo not only forced his colleague to critically investigate his own findings, but also made the otological community more aware of Dorello's work. In fact, Gradenigo's 1907 publication, which challenges Dorello's hypothesis, contains a comprehensive summary of Dorello's findings (note that our additions to the quoted, translated material appear in the inner brackets):

[The relationships of the N. abducens in this area [pyramid] have been described in detail by Dorello [extensive summary of Dorello's findings].... From the detailed description of Dorello it is understood that the N. abducens and the inferior petrosal sinus are in a close relationship where the nerve enters the dura mater and extends through the mentioned osteofibrous canal, where it can be easily compressed and isolated. Immediately after leaving that space the nerve makes a slight curve and enters the cavernous sinus, coming into close relations with the carotid artery. Now, suppose that the lesion of the abducens occurs along with acute purulent otitis media in the area of the top of the pyramid, is the mechanism [of infection and abducent paralysis] the same? $]^{23}$

Gradenigo continues this discussion with a series of questions and challenges to Dorello's hypothesis. Nevertheless, his early critical summary of Dorello's work was so accurate and concisely written that it was translated and quoted by Harris Vail to form the body of his 1922 publication on Dorello's canal..$^{56}$ Thus, Gradenigo, by setting the stage for the investigations of the canal with his work on his eponymous syndrome and his critique of Dorello's work, played a unique role in contributing to the understanding of Dorello's canal.

\section{Primo Dorello (1872-1963)}

Primo Dorello (Fig. 4) was born on September 27, 1872, in the hill town of Narni, Italy. ${ }^{5}$ In 1897, at the age of 25, he graduated with high honors from the University of Rome with a degree in medicine and surgery. In fact, his final thesis was so well researched that it was submitted in a competition coordinated by the prestigious Girolami Foundation. Following his graduation, Dorello worked in the Department of Normal Human Anatomy at the University of Rome as an assistant under the guidance of Professor Francesco Todaro. It was also in this position that Dorello began his studies of the now well-known "Dorello's canal."' 5,20

In his 1905 publication, ${ }^{19}$ which was highly detailed for a study done without a dissecting microscope, Dorello identified a bony process, termed the spina sphenoidalis, located approximately 4 or $5 \mathrm{~mm}$ from the tip of the petrous bone. ${ }^{23,56}$ Within this region he found a depression near the petrous apex, which was surrounded by the petrosphenoidal suture and the superior border of the lamina quadrangularis. At the anterior end of the lamina quadrangularis he identified the posterior clinoid process. Dorello noticed that in some individuals there was another smaller bony process that protruded slightly outward that was located below the posterior clinoid, which he called "the accessory process of the posterior clinoid." Despite the variation, Dorello discovered that this depression at the petrous apex created a sinus between the spina sphenoidalis and the posterior clinoid process that transformed into an osteofibrous canal when bounded superiorly by the petrosphenoidal ligament of Gruber. This canal, as described by Dorello, is an approximately triangular space bordered by the petrous bone, the edge of the lamina quadrangularis, and the petrosphenoidal ligament of Gruber. Dorello, like Gruber, also found that the abducent nerve and inferior petrosal sinus pass through this rigid canal. ${ }^{19,23,56}$

In the years after the controversy surrounding Gradenigo's syndrome subsided, Dorello devoted himself to continuing various anatomical studies. His knowledge also proved useful during his 3-year military service (1915-1918) in World War I. ${ }^{5}$ Due in part to his accomplishments and the respect he garnered during his time in Rome, in 1922 Dorello became a professor in the Department of Human Anatomy in Sassari and then in Camerino. Four years later, in 1926, Dorello was unanimously chosen as Chair of the Department of Human Anatomy in Perugia. ${ }^{5,20} \mathrm{He}$ retired from this position in 1946, upon which he received the honor of Professor Emeritus. During his years in Perugia, Dorello came to be highly esteemed by his students and colleagues, despite his reserved and private nature. As a professor he continued to be highly productive in research, publishing about 100 works and trying to increase student involvement in his investigations..$^{5}$ Toward the end of his prolific academic career, Dorello held several leadership positions. In 1939, Dorello became the Dean of the Faculty of Medicine and Surgery in Perugiaa position he held until 1941., ${ }^{50}$ Not surprisingly, Dorello also had the honor of being a nominator for the 1939 Nobel Prize in Physiology or Medicine due to his reputable position and lifelong dedication to studying anatomy (http:// www.nobelprize.org/nomination/medicine/nomination. php?action=show\&showid=495).

Beyond his remarkable contributions to the fields of anatomy and medicine, Dorello also demonstrated interest in cultural organizations, anthropology, and photography. ${ }^{5,20}$ Indeed, even after his retirement in 1946, he continued to visit his peers in Perugia and maintained an enduring presence in academia. He researched the history of the Roman Empire, astronomy, the physics of sound, and enjoyed tinkering as a mechanic-a hobby that most certainly benefitted him during the delicate anatomical dissections he performed. For his lifelong dedication to advancing the medical field, he was honored as the "figlio illustre" (illustrious son) of his hometown, Narni, in 1959. ${ }^{5}$

Dorello died in Bologna on January 17, 1963, at the age of 90 , surrounded by the comfort of his admiring colleagues, past students, and family. In writing about Dorello, Giacomo Andreassi, Dorello's successor as Chair of the Department of Human Anatomy in Perugia, remarked that although Dorello was well respected and highly esteemed during his time, one could say that his name deserved even greater recognition. ${ }^{5}$ By daring to look beyond the theories of leaders in the otological community like Gradenigo, and to conduct his own studies in the pursuit of solving challenging otological questions, Dorello's open-mindedness led to the rediscovery of a critical anatomical feature 
that had gone unnoticed since the works of Gruber. However, as noted by Andreassi, Dorello's name and his pivotal works were immortalized not by his own Italian otological community, but rather by the works of an American, Harris Vail, who was one of the first people to credit, favorably appreciate, and validate Dorello's findings regarding the canal. ${ }^{5}$

\section{Harris Holmes Vail (1892-1939)}

An ocean away, a recent graduate of Harvard Medical School, ${ }^{34}$ Harris Vail, was following the work of Dorello and Gradenigo regarding the anatomy of Dorello's canal. Struck by the lack of publications relating to Dorello's canal in the English literature, Vail was interested in performing his own systematic studies of the canal to investigate these reports from European studies. ${ }^{56}$ It was on this path that Vail became the first to describe the anatomy of the canal in the English-speaking community, and he immortalized the eponym "Dorello's canal."

Harris Holmes Vail (Fig. 5) was born on January 9, 1892, in Cincinnati, Ohio. ${ }^{61,49}$ After completing his early education at the Franklin School, Harris Vail went to Yale University to obtain his undergraduate degree as part of the Class of 1912. During his time at Yale, he expressed a diverse range of interests, including science, baseball, hockey, wine tasting, and yachting. ${ }^{49}$

In 1917, Vail obtained his medical degree from Harvard Medical School with High Honors ${ }^{34}$ and received further training from the Massachusetts Eye and Ear Infirmary. ${ }^{6}$ Upon his graduation, however, Vail was immediately recruited to serve as a military surgeon during World War I. In May 1917, he was enlisted as a member of the Harvard Base Hospital unit No. 5, under the direction of Dr. Harvey Cushing, one of the six base hospital units that was rapidly mobilized and sent to France to assist the European Allies. ${ }^{9}$ Under Cushing's leadership, Vail was exposed to many innovative procedures because the base hospitals were often burdened with the task of treating large groups of men. Throughout the war, Vail was transferred to several naval hospitals until he was ultimately discharged from active duty in 1919, after more than 2 years of active military service. ${ }^{35}$

In the early 1920s Vail began working with his brother, Dr. Derrick T. Vail Jr., in a private practice in Ohio.,61 During his spare time Vail worked on publishing his earlier anatomical studies on Dorello's canal, which were conducted at Harvard Medical School in the laboratory of Dr. Harris P. Mosher. ${ }^{56}$ Vail prefaces his article published in 1922 by stating, "My interest in Dorello's canal was stimulated by two recent cases of sixth nerve involvement at the Massachusetts Charitable Eye and Ear Infirmary, Boston, and on looking up the subject I was surprised to find very little mention in American literature on Dorello's canal. I found, however, an accurate description by Gradenigo, who apparently quoted from Dorello's original article."56

Amazed to find a region of key clinical importance so under-studied, Vail felt compelled to conduct his own

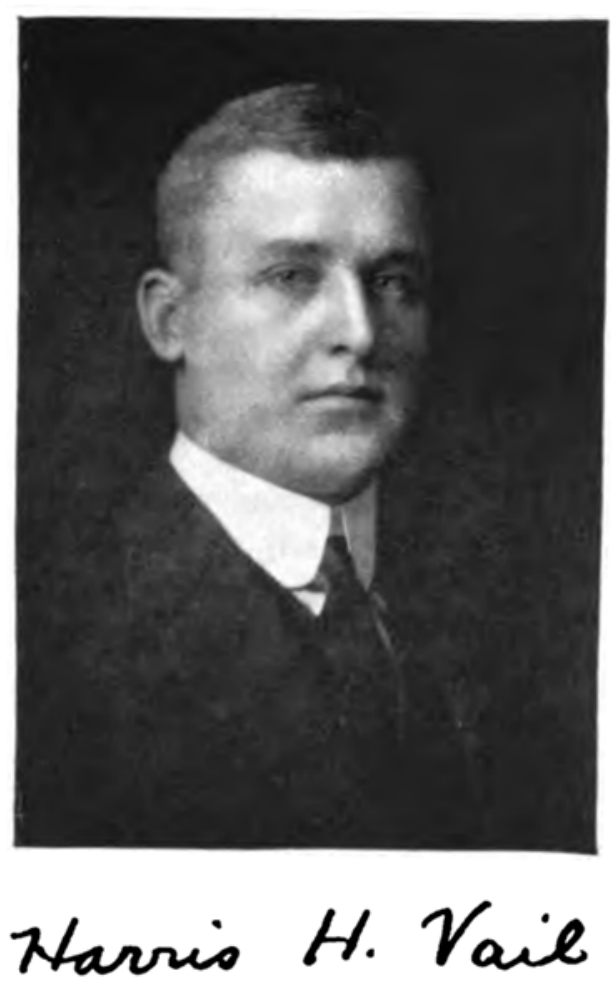

\section{Tн}

\section{LARYNG OSCOPE.}

\author{
$\begin{array}{lll}\text { Vot. XXXII } & \text { ST. LOUIS, AUGUST, } 1922 & \text { No. } 8\end{array}$
}

\section{ORIGINAL COMMUNICATIONS.}

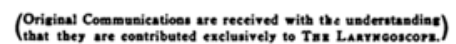
Eye and Ear Infirmary, Boston, and on looking up the subject I was surprised to find very little mention in American literature on Dorello's canal. I found, however, an accurate description by Gradenigo $0^{1}$, who apparently quoted from Dorello's original article: My abridged trasiation of Gradcigo's description of Dorello's My abridged transiation of Gradenigo's description of Dorello's canal is as follows:

"The sulcus petrosus superioris disappears 4 to $5 \mathrm{~mm}$. proximal to the apex of the petrous portion of the temporal bone and there appears in its place a bony process of various form and strength the apex of which is directed upwards, inwards and forwards, in the apex of which is directed upwards, inwards and forwards, in
other words, toward the processus clinoidei posticus. This process, called by Dorello, the spina sphenoidalis, represents the continuation of the posterior lip of the superior petrosal sulcus. The superior petrosal sinus bends somewhat outwards from the spine anteriorly to run into the cavernous sinus.

Inwards from the spine in a somewhat deep plane, there is a depression corresponding to the apex of the petrous bone. Then there follows the petro-sphenoidal suture and finally the outer border of the lamina quadrangularis of the sphenoid bone, which exhibits a variable form and strength. In many cases this lamina quadrangularis describes the third of a circle in its course, the upper end of which is formed by the apex of the posterior clinoid process, in other instances it is divided into two parts through a small bony process which, somewhat below the posterior clinoid

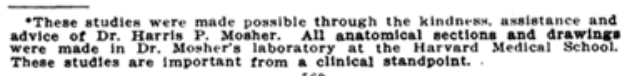

FIG. 5. Left: Portrait of Harris Vail (from Proctor MR: Harris H. Vail, in History of the Class of 1912 Yale College. New Haven: Yale University, 1912, Vol 1, p 317). Right: Vail's original publication in The Laryngoscope validating Dorello's findings and popularizing the term "Dorello's canal." From Vail HH: Laryngoscope 32:569-575, 1922. 


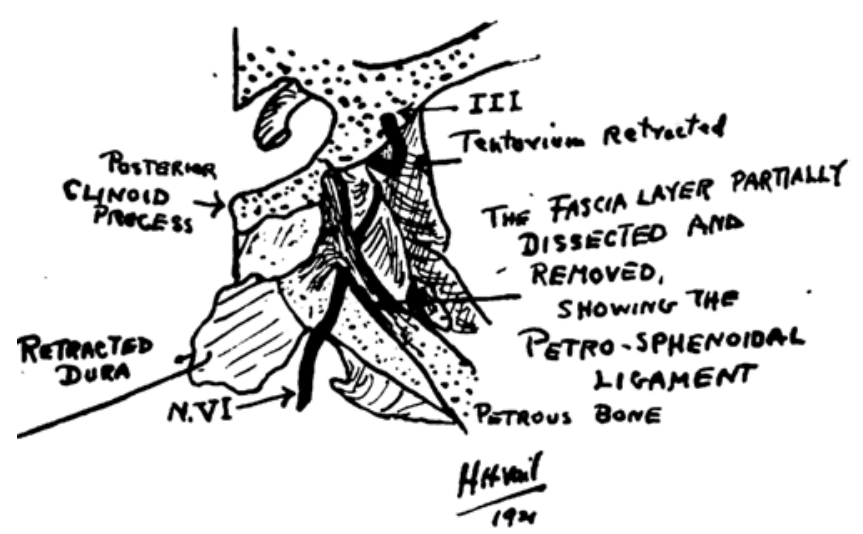

FIG. 6. Vail's illustration showing attachments to the petrosphenoidal ligament and its relations to the abducent nerve (N. VI), from Vail HH: Laryngoscope 32:569-575, 1922.

investigations. His study consisted of observations of 8 specimens, including an 8-month-old fetus. ${ }^{56}$ Through careful observation he confirmed Dorello's descriptions of the petrous apex, spina sphenoidalis, petrosphenoidal ligament, and the path of the abducent nerve in relation to the canal. He also found variations in the structure of the spina sphenoidalis and discovered a minor artery (meningeal artery) that ran medial to the abducent nerve. His findings were primarily reported in the form of his dissection illustrations (Fig. 6). Ultimately, his work was the first widely recognized anatomical study published in the
English language to use the term "Dorello's canal"- thus, Vail popularized the eponym used today. In addition to recapitulating the anatomical descriptions that were initially published by Dorello, Vail also concluded his article by reiterating the clinical importance of the canal, with particular regard to abducent palsy due to infection and inflammation: "Dorello's canal, affording passage for the sixth nerve, its accompanying artery and inferior petrosal sinus, becomes an exceedingly important structure in certain pathological states where inflammatory swelling may readily cause the trunk of the nerve to be inflamed or compressed; thus producing abducent palsy." 56

Vail's statement had the potential to bolster continued study of the canal; however, clinical interest in the canal diminished in the following years, as the antibiotic era flourished and ear infections were easily treated with medication, reducing the need for invasive surgical procedures to alleviate infections..$^{13,16,20,40}$ It was not until the 1970s that investigations of the variations in the course of the abducent nerve and microanatomical nuances of the canal began to resurface (Fig. 7)..$^{17,18,36,37,45,53,55}$ Although initial interest in Dorello's canal was centered on abducent palsy in association with acute or chronic otitis media, the modern clinical relevance of the canal is extensive. As surgical technology and approaches to the petroclival region improved in the late 20 th century, the clinical focus shifted toward tumors of the skull base, ${ }^{1,44}$ aneurysms of surrounding vasculature ${ }^{4}$ (such as the internal carotid artery), and other brain injuries. ${ }^{38,41,47}$ The canal once again

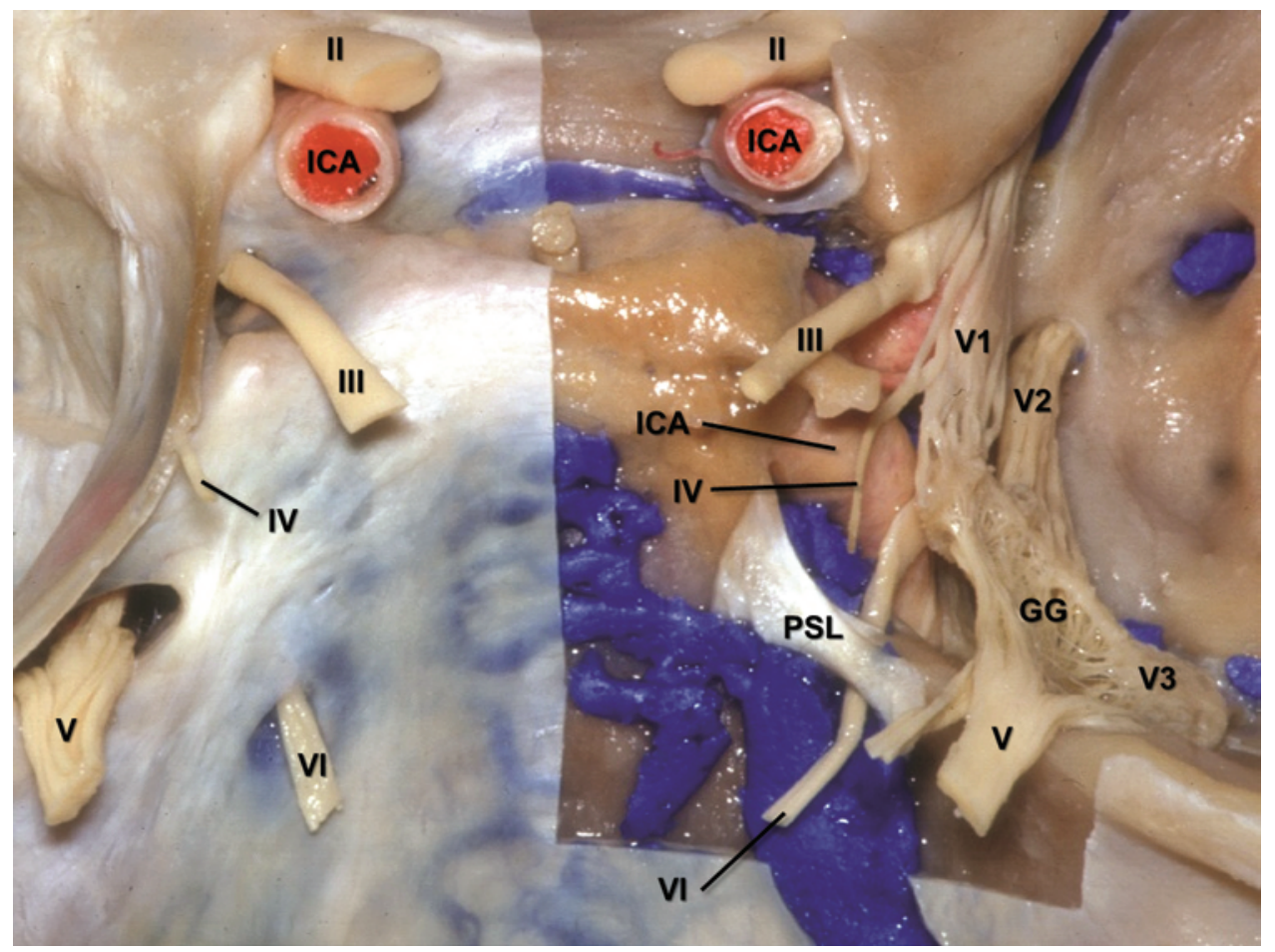

FIG. 7. Photograph of a modern microanatomical cadaver dissection demonstrating Dorello's canal, the abducent nerve, and surrounding structures. The petrosphenoidal ligament is exposed after removal of the petroclival venous confluence. $\mathrm{GG}=\mathrm{Gasserian}$ ganglion; ICA = internal carotid artery; II = optic nerve; III = oculomotor nerve; IV = trochlear nerve; PSL = petrosphenoidal ligament (Gruber's ligament); $V=$ trigeminal nerve; $\mathrm{VI}=$ abducent nerve; $\mathrm{V} 1=1$ st division (ophthalmic) of trigeminal nerve; $\mathrm{V} 2=2 \mathrm{nd}$ division (maxillary) of trigeminal nerve; $V 3=3$ rd division (mandibular) of trigeminal nerve. Courtesy of Professor Albert $L$. Rhoton. Figure is available in color online only. 
became important to study due to its narrow structure and vulnerability to damage from compression or torsional strain.

In the years following his study of Dorello's canal, Vail continued to study the sphenoid bone and sinus. In 1923 he became an assistant in the Department of Otolaryngology at the University of Cincinnati, and later a professor at the university and an attending laryngologist at the Cincinnati General Hospital ${ }^{61}$ In 1929 he published a case report on vidian neuralgia ${ }^{59}$ (commonly known as the cluster headache) resulting from disease of the sphenoidal sinus. This report was followed by several investigations into the causes and pathways of pain in vidian neuralgia. ${ }^{57,58,60}$ Tragically, on April 19, 1939, Vail died at the age of $47 .{ }^{61}$ Due to his contributions to the understanding of vidian nerve syndrome, however, his name lives on through the eponym "Vail's neuralgia." Nevertheless, it is essential that his work as one of the first to take on the feat of precisely validating Dorello's findings and furthering the collective understanding of Dorello's canal in the English literature is not forgotten.

\section{Conclusions}

While modern-day anatomists are still seeking to define the boundaries and characteristics of Dorello's canal, these contemporary investigations might not have been possible without the dedicated efforts of men like Gruber, Gradenigo, Dorello, and Vail. The works of this lineage of anatomists and otologists formed the foundation on which modern studies have developed. By examining the personal lives of these men, we see that they had many talents. They were ambitious, had diverse interests, and contributed to the advancement of their countries, either through scholarly work and academic programs or through their involvement in military efforts. Ultimately, it is important that their lives and contributions be appreciated as a lineage so that the relationships between the invaluable efforts taken by these men to lead to the modern state of anatomical understanding are never forgotten.

\section{References}

1. Al-Mefty O, Fox JL, Smith RR: Petrosal approach for petroclival meningiomas. Neurosurgery 22:510-517, 1988

2. Ambekar S, Sonig A, Nanda A: Dorello's canal and Gruber's ligament: historical perspective. J Neurol Surg B Skull Base 73:430-433, 2012

3. American Medical Association: The death of Giuseppe Gradenigo: JAMA 86:1710, 1926

4. Anderson RD, Liebeskind A, Schechter MM, Zingesser LH: Aneurysms of the internal carotid artery in the carotid canal of the petrous temporal bone. Radiology 102:639-642, 1972

5. Andreassi G: Primo Dorello 1872-1963. Ricerche di Morfologia 28-29:5-9, 1963

6. Archives of Ophthalmology: Obituary: Derrick T. Vail, M.D. (1864-1930). Arch Opthalmol 4:978, 1930

7. Baldenweck L: [Anatomical research on the petrosal apex.] Annales des Maladies de l'Oreille du Larynx, du Nez et du Pharynx 33:122-137, 1907 (Fr)

8. Baratoux J: [Paralysis of the abducens in the ear.] Arch Int de Laryngologie, d'Otologie et de Rhinologie 23:415-448, 1907 (Fr)

9. Boston Medical and Surgical Journal: Harvard Base Hospital Unit. Boston Med Surg J 176:712-713, 1917
10. Boston Medical and Surgical Journal: Necrology.-Foreign. Wenzel Gruber. Boston Med Surg J 123:628, 1890

11. British Medical Journal: Obituary for 1890. Austria-Hungary. BMJ 2:1503, 1890

12. Celestino D: Gradenigo, Giuseppe. Dizionario Biografico degli Italiani. (http://www.treccani.it/enciclopedia/giuseppegradenigo_res-3a31ca6c-87ee-11dc-8e9d-0016357eee51_ (Dizionario-Biografico)/) [Accessed April 30, 2015]

13. Choi KY, Park SK: Petrositis with bilateral abducens nerve palsies complicated by acute otitis media. Clin Exp Otorhinolaryngol 7:59-62, 2014

14. Citelli S: [On the paralysis of the abducent of otitic origin and its clinical significance.] Arch Ital Otol Rinol Laringol 15:407-413, 1904 (Ital)

15. Csendes P, Obermayer-Marnach E, Santifaller L: Gruber, Wenzel, in Österreichisches Biographisches Lexikon 18151950. Vienna: Austrian Academy of Sciences, 1993, Vol 2, pp 84

16. de Graaf J, Cats H, de Jager AE: Gradenigo's syndrome: a rare complication of otitis media. Clin Neurol Neurosurg 90:237-239, 1988

17. Destrieux C, Velut S, Kakou MK, Lefrancq T, Arbeille B, Santini JJ: A new concept in Dorello's canal microanatomy: the petroclival venous confluence. J Neurosurg 87:67-72, 1997

18. Dolenc VV, Yaşargil MH: Anatomy and Surgery of the Cavernous Sinus. New York: Springer, 1989

19. Dorello P: [Considerations concerning the cause of temporary paralysis of the abducent in middle ear inflammation.] Atti della Clinica Oto-Rino-Laringoiatrica della R. Universitá di Roma 3:209-217, 1905 (Ital)

20. Felisati D, Sperati G: Gradenigo's syndrome and Dorello's canal. Acta Otorhinolaryngol Ital 29:169-172, 2009

21. Geronzi G: [On the paralysis of the abducent of otitic origin.] Atti della Clinica Oto-Rino-Laringoiatrica della R. Università di Roma, 1904 (Ital)

22. Gradenigo G: [About circumscribed leptomeningitis with spinal symptoms and about paralysis of the abducent nerve of otitic origin.] Arch Ohrenheilk 62:255-270, 1904 (Ger)

23. Gradenigo G: [About the paralysis of the abducens nerve in otitis.] Archiv Uhrenheil 74:149-187, 1907 (Ger)

24. Gradenigo G: [The embryonic system of the middle ear: the morphological importance of the ossicles.] Medizinische Jahrbücher 83:219-308, 1887 (Ger)

25. Gradenigo G: [On the paralysis of the abducent of otitic origin.] Arch Ital Otol Rinol Laringol 15:402-403, 1904 (Ital)

26. Gradenigo G: [On a particular syndrome of intracranial otitic complications: Paralysis of the abductor of otitic origin.] Annales des Maladies de l'Oreille, du Larynx, du Nez et du Pharynx 30:120-152, 1904 (Fr)

27. Gruber W: [About the cervical ribs of humans with comparative anatomical observations.] Mém Acad Imp Sci St Pétersbourg 13:1-52, 1869 (Ger)

28. Gruber W: [About the infraorbital canal in humans and mammals.] Mém Acad Imp Sci St Pétersbourg 21:3-27, 1874 (Ger)

29. Gruber W: [Anomalous formation with inhibited development caused by bipartition of both patellae of young subjects.] Arch Pathol Anat Physiol Klin Med 94:358-361, 1883 (Ger)

30. Gruber W: [Contributions to the anatomy of the skull base.] Mém Acad Imp Sci St Pétersbourg 13:1-34, 1869 (Ger)

31. Gruber W: [Contributions to the anatomy of the sphenoid and the temporal bone.] Mém Acad Imp Sci St Pétersbourg 1:3-13, 1859 (Ger)

32. Gruber W: [Duplicity of the superior vena cava, with occurrence of two azygos veins and a sufficient valve at the mouth of the azygos vein.] Arch Pathol Anat Physiol Klin Med 81:462-465, 1880 (Ger) 
33. Gruber W: [Lack of the middle portion of the deltoid.] Arch Pathol Anat Physiol Klin Med 54:184-185, 1872 (Ger)

34. Harvard University: Catalogue of Names (1917-18). Cambridge: Harvard University, 1917, pp 284

35. Harvard War Records Office: Vail, Harris Holmes, in Mead FS (ed): Harvard's Military Record in the World War. Boston: Harvard Alumni Association, 1921, p 967

36. Iaconetta G, Fusco M, Samii M: The sphenopetroclival venous gulf: a microanatomical study. J Neurosurg 99:366375, 2003

37. Joo W, Yoshioka F, Funaki T, Rhoton AL Jr: Microsurgical anatomy of the abducens nerve. Clin Anat 25:1030-1042, 2012

38. Kshettry VR, Lee JH, Ammirati M: The Dorello canal: historical development, controversies in microsurgical anatomy, and clinical implications. Neurosurg Focus 34(3):E4, 2013

39. Malakhova O: Nikolay Ivanovich Pirogoff (1810-1881). Clin Anat 17:369-372, 2004

40. Marianowski R, Rocton S, Ait-Amer JL, Morisseau-Durand MP, Manach Y: Conservative management of Gradenigo syndrome in a child. Int J Pediatr Otorhinolaryngol 57:79-83, 2001

41. Marom A: A new look at an old canal. Skull Base 21:53-58, 2011

42. Matis GK, de A Silva DO, Chrysou OI, Karanikas MA, Birbilis TA: Giuseppe Gradenigo: Much more than a syndrome! Historical vignette. Surg Neurol Int 3:122, 2012

43. Mongardi R: [A case of paralysis of the VI nerve of otitic origin.] Arch Ital Otol Rinol Laringol 15:404-406, 1904 (Ital)

44. Nakagawa T, Uchida K, Ozveren MF, Kawase T: Abducens schwannoma inside the cavernous sinus proper: case report. Surg Neurol 61:559-563, 2004

45. Nathan H, Ouaknine G, Kosary IZ: The abducens nerve. Anatomical variations in its course. J Neurosurg 41:561-566, 1974

46. Nature: Notes. Nature 42:597, 1890

47. Ozveren MF, Erol FS, Alkan A, Kocak A, Onal C, Türe U: Microanatomical architecture of Dorello's canal and its clinical implications. Neurosurgery 60 (2 Suppl 1):ONS1ONS8, 2007

48. Politzer A: La Dissection Anatomique et Histologique de l'Organe Auditif de l'Homme à l'État Normal et Pathologique à l'Usage des Anatomistes, des Médecins Auristes et des Étudiants. Paris: Octave Doin and Charles Desoer, 1898

49. Proctor MR: Harris H. Vail, in History of the Class of 1912 Yale College. New Haven: Yale University, 1912, Vol 1, pp 317
50. Sorokina T: The great Russian surgeon Nikolay Ivanovich Pirogov (1810-1881). Vesalius 17:10-15, 2011

51. Sperati G, Felisati D: Birth and development of otorhinolaryngology (ORL) in Italy. J Laryngol Otol Suppl 30:60-63, 2005

52. Stephens D, Orzan E, Galleti Di San Cataldo F: Giuseppe Gradenigo and his contributions to audiology. J Laryngol Otol 111:418-423, 1997

53. Tsitsopoulos PD, Tsonidis CA, Petsas GP, Hadjiioannou PN, Njau SN, Anagnostopoulos IV: Microsurgical study of the Dorello's canal. Skull Base Surg 6:181-185, 1996

54. Turner WM: Report on the progress of anatomy. J Anat Physiol 6:433-449, 1872

55. Umansky F, Elidan J, Valarezo A: Dorello's canal: a microanatomical study. J Neurosurg 75:294-298, 1991

56. Vail HH: Anatomical studies of Dorello's canal. Laryngoscope 32:569-575, 1922

57. Vail HH: Pathways of reflex pain in vidian neuralgia. Arch Otolaryngol 21:277-284, 1935

58. Vail HH: Vidian neuralgia. Ann Otol Rhinol Laryngol 41:837-856, 1932

59. Vail HH: Vidian neuralgia from disease of the sphenoidal sinus: report of a case. Arch Surg 18:1247-1255, 1929

60. Vail HH: Vidian neuralgia with special reference to the eye and orbital pain in suppuration of the petrous apex. Arch Otolaryngol 17:212-221, 1933

61. Yale University: Harris Holmes Vail B.A. 1912, in Bulletin of Yale University: Obituary Record of Graduates of Yale University Deceased During the Year 1938-1939. New Haven: Yale University, 1940, Vol 36, pp 142-143

\section{Author Contributions}

Conception and design: Liu. Acquisition of data: Liu, RK Reddy, RK Reddy. Analysis and interpretation of data: Liu, RK Reddy, RK Reddy. Drafting the article: RK Reddy, RK Reddy. Critically revising the article: all authors. Reviewed submitted version of manuscript: all authors. Approved the final version of the manuscript on behalf of all authors: Liu. Administrative/technical/ material support: Liu. Study supervision: Liu.

\section{Correspondence}

James K. Liu, Center for Skull Base and Pituitary Surgery, Department of Neurological Surgery, Rutgers University, New Jersey Medical School, 90 Bergen St., Ste. 8100, Newark, NJ 07103. email: james.liu.md@rutgers.edu. 